\title{
Problem-based learning as an efficient teaching modality: improvements proposed by UK medical students
}

This article was published in the following Dove Press journal:

Advances in Medical Education and Practice

\section{Mohammed Khalid Aslami \\ Amir-Humza Tahir Suleman Owais Ali Shah}

Faculty of Medicine, St George's Hospital Medical School, London, UK

Correspondence: Mohammed Khalid Aslami

Faculty of Medicine, St George's Hospital Medical School, Cranmer Terrace, London SWI7 ORE, UK Email kha.aslamil@gmail.com

\section{Dear editor}

We read the article by Yadav et $\mathrm{al}^{1}$ with great interest which highlighted the positive perception of medical students toward problem-based learning (PBL). Surprisingly, however, over half of the participants deemed PBL as a time-consuming teaching method. This is supported by a study wherein $32.9 \%$ of respondents detailed PBL to be time inefficient, highlighting potential concerns regarding its ability to adequately meet learning outcomes. ${ }^{2}$ As penultimate year medical students studying a curriculum utilizing PBL, we would like to use our experience to propose improvements that can be made to PBL teaching.

The paper highlighted the positive view students have of tutors in stimulating discussions. From our experience, we agree with this, but we think the tutor can also play a vital role in improving time efficiency of sessions. Some common reasons for inefficiency not discussed by the authors could be related to the quality of written cases, group cohesion, or poor timekeeping. To help tutors address such problems, we propose some improvements.

First, we suggest introducing standardized training amongst PBL tutors. This not only improves tutor competency as facilitators of productive PBL discussions but also reduces variability in the delivery of sessions. Such methods have already been shown to enhance student satisfaction with tutor performance. ${ }^{3}$ Second, inviting feedback from students would give tutors the opportunity to make relevant changes to the sessions. Third, tutors could meet regularly to share PBL experiences. As a result, case designs can be improved through discussion to ensure time efficiency. Additionally, this provides an opportunity to identify commonly occurring problems and devise solutions. ${ }^{4}$

Finally, standardized assessments can be utilized to maximize learning. Problem analysis, self-directed learning, and reporting phase are three distinct but interdependent stages of PBL; each stage prepares students for learning in the next step. As medical students, we believe that self-directed learning is the most important part of this process. Unfortunately, it is very common to see low levels of self-directed learning by some students in the group before the reporting phase. We believe that the introduction of a multiple choice styled assessment would help tackle this issue. This approach has been shown to improve student achievement. ${ }^{5}$ The quiz would ideally take place before the reporting phase consisting of questions designed by the universities based 
on the learning objectives of students. This will ensure that every student is on the same level or at least aware of the expectation from them.

We commend the authors for completing an insightful study exploring medical student views on PBL. We must stress, however, that the participants were exclusively firstyear medical students at one institution. A multi-institutional study investigating a sample comprising medical students across all year groups would have improved the generalizability of findings. PBL is already well established, and students are receptive to its incorporation into university curricula as highlighted in this study. We, however, feel there is room for improvement in medical student perspectives on PBL particularly with regard to its time efficiency. We believe the suggested improvements can provide a possible avenue for achieving this.

\section{Disclosure}

The authors report no conflicts of interest in this communication.

\section{References}

1. Yadav RL, Piryani RM, Deo GP, Shah DK, Yadav LK, Islam MN. Attitude and perception of undergraduate medical students toward the problembased learning in Chitwan Medical College, Nepal. Adv Med Educ Pract. 2018;9:317-322.

2. Huang R. Chinese international students' perceptions of the problem-based learning experience. J Hosp Leis Sport Tour Educ. 2005;4(2):36-43.

3. El Aziz El Naggar MAA, Maklady FAH, Hamam AM, Omar AS. Effectiveness of implementing a tutor training workshop for problem based learning class tutors at the Faculty of Medicine, Suez Canal University. Intellect Prop Rights Open Access. 2013;1(1):1-10.

4. Chan LC. The role of a PBL tutor: a personal perspective. Kaohsiung $J$ Med Sci. 2008;24(3 Suppl):S34-S38.

5. Bestetti RB, Couto LB, Restini CB, Faria M, Romão GS. Assessment test before the reporting phase of tutorial session in problem-based learning. Adv Med Educ Pract. 2017;8:181-187. 


\section{Authors' reply}

Ram Lochan Yadav'

Rano Mal Piryani

Gopendra Prasad Deo 3

Dev Kumar Shah ${ }^{4}$

Laxmi Kumari Yadav ${ }^{5}$

Md Nazrul Islam ${ }^{4}$

'Department of Physiology, Faculty of Basic Science, Chitwan Medical College (CMC) Affiliated to Tribhuvan University

(TU), Bharatpur, Nepal; ' Department of Internal Medicine and Health Professional Educational Research Center (HPERC), Chitwan Medical College, Bharatpur, Nepal; ${ }^{3}$ Department of Anaesthesiology and Critical Care, Chitwan Medical College, Bharatpur, Nepal; ${ }^{4}$ Department of Physiology, Chitwan Medical College, Bharatpur, Nepal; ${ }^{5}$ Department of Microbiology, Chitwan Medical College, Bharatpur, Nepal

Correspondence: Ram Lochan Yadav

Department of Physiology, Faculty of Basic Science, Chitwan Medical College (CMC) Affiliated to Tribhuvan University (TU), Bharatpur, Nepal

Tel +9779848096590

Email drramlochan04@gmail.com

\section{Dear editor}

First, we would like to thank and appreciate Aslami et al for their valuable suggestions noted as improvements proposed by UK medical students. We, personally, do agree with the letter that time can be managed efficiently during the problembased learning (PBL) sessions. In our opinion, time duration of PBL sessions depends mainly on the three vital pillars of PBL: PBL case/scenario, tutors, and students in the group.

Effective PBL case/scenario for managing time: PBL case chosen should be interest arousal to students. The number and content of specific learning objectives in triggers of $\mathrm{PBL}$ should be in limit so that the students can easily cover it during the self-study as well as in group discussions. ${ }^{1}$ If the learning objectives are too many, students will not be able to study and prepare up to a level in the very short allotted time, and therefore, the discussions made by students will be less fruitful.

Role of tutor in managing time: Of course, we should always introduce well-trained tutors in PBL sessions as suggested by Aslami et al in their letter. Moreover, we have clearly mentioned in our published article that all the tutors had already participated in the PBL training conducted during "Teaching training workshops in CMC". ${ }^{2}$ No doubt, standardized tutors certainly reduce the variations among groups. The only feedback from the students and standardized tutors in PBL would not be sufficient to make homogeneity in PBL tutorial sessions. There is always a probability of individual variation no matter how much the enrolled tutors are standardized. ${ }^{3}$ Therefore, some special kind of supervision and monitoring (eg, live webcast) to all the groups at one time is required.

Students in the group: We usually assume that all the medical students in a medical school are having the same motivation and dedication toward self-directed learning. Few students complete the assigned task within the time, whereas others require more time and more supervision to complete the same task keeping the other conditions same. Therefore, the students are not the same and they have different learning styles too. ${ }^{4}$ On the other hand, all the students have to participate equally and move together in PBL group sessions, though they have different speeds of learning and grasping abilities. Therefore, the logical finding of our study is that to complete the same learning objectives effectively and efficiently, PBL method will take more time than the conventional lecture method.

However, the suggestions made by Aslami et al in PBL as an efficient teaching modality - improvements proposed by UK medical students are appreciable, the points we put in above discussions likely to be included in the discussions.

\section{Disclosure}

The authors report no conflicts of interest in this communication.

\section{References}

1. Hung, W. The 3C3R model: a conceptual framework for designing problems in PBL. Interdisciplinary Journal of Problem-Based Learning. 2006;1(1):55-77.

2. Yadav RL, Piryani RM, Deo GP, Shah DK, Yadav LK, Islam MN. Attitude and perception of undergraduate medical students toward the problembased learning in Chitwan Medical College, Nepal. Adv Med Educ Pract. 2018;9:317-322.

3. McLean M. Clinical role models are important in the early years of a problem-based learning curriculum. Med Teach. 2006;28(1):64-69.

4. JDunlosky J, Rawson KA, Marsh EJ, Nathan MJ, Willingham DT. Improving students' learning with effective learning techniques: promising directions from cognitive and educational psychology. Psychol Sci Public Interest. 2013;14(1) 4-58. 
Dove Medical Press encourages responsible, free and frank academic debate. The content of the Advances in Medical Education and Practice 'letters to the editor' section does not necessarily represent the views of Dove Medical Press, its officers, agents, employees, related entities or the Advances in Medical Education and Practice editors. While all reasonable steps have been taken to confirm the content of each letter, Dove Medical Press accepts no liability in respect of the content of any letter, nor is it responsible for the content and accuracy of any letter to the editor.

Advances in Medical Education and Practice

Dovepress

\section{Publish your work in this journal}

Advances in Medical Education and Practice is an international, peerreviewed, open access journal that aims to present and publish research on Medical Education covering medical, dental, nursing and allied health care professional education. The journal covers undergraduate education, postgraduate training and continuing medical education research, and health care services. The manuscript management system is completely online and includes a very quick and fair peer-review system. Visit http://www.dovepress.com/testimonials.php to read real quotes from published authors.

Submit your manuscript here: http://www.dovepress.com/advances-in-medical-education-and-practice-journal 